\title{
In the Field: Coase an Exemplar in the Tradition of Smith, Marshall and Ostrom
}

\author{
Gavin C. Reid
}

This is the peer reviewed version of the following article:

Reid, G.C. 2015. In the field: Coase an exemplar in the tradition of Smith, Marshall and Ostrom. Managerial and Decision Economics. 36(1): pp.16-32. Available from DOI: http://dx.doi.org/10.1002/mde.2703

which has been published in final form at: http://dx.doi.org/10.1002/mde.2703. This article may be used for non-commercial purposes in accordance with Wiley Terms and Conditions for self-archiving. 
In the Field: Coase an Exemplar in the Tradition of Smith, Marshall and Ostrom By Gavin C Reid

\begin{abstract}
This paper argues that Coase provides the primary $20^{\text {th }}$ Century exemplar of the grounding of analytical developments in economics in direct field-work observation. In particular, his focus on the business enterprise, its internal functions (including decisions making), and its external relations (including contracting) has provided a stimulus for radical developments in microeconomics, and in managerial and decision economics in particular. The argument is developed by a stylization of the development of economics, referring to Adam Smith in the $18^{\text {th }}$ Century, Alfred Marshall in the $19^{\text {th }}$ century, Ronald Coase in the $20^{\text {th }}$ century, and Elinor Ostrom in the $21^{\text {st }}$ century.
\end{abstract}

\title{
In the Field: Coase an Exemplar in the Tradition of Smith, Marshall, and Ostrom
}

\section{INTRODUCTION}

The context of this paper is the grounded approach to analytical developments in economics, which turns our attention to a little discussed aspect of Ronald Coase's endeavours. This is his work 'in the field': that is, out in the real world of business and management, examining how decisions are made in practice cf. McCloskey (1985), Nell and Errovaki (2013, Ch. 10), Swann (2008), Reid (1987), and Helper (2000). His focus is on practice, rather than on imputing behaviour to some maxim, be it satisficing, rule of thumb, utility maximization, or whatever. In doing so, this paper identifies Coase as being other than an 'outlier', but rather as being part of a distinguished tradition of field-work observation and analysis that extends from the roots of political economy in the eighteenth century, to the flowering of the new institutional economics in the twenty first century. It does so by reference to key figures in each century, whose similarity in approach is expounded and noted. The argument is progressed by a stylization of intellectual development, referring to Adam Smith in the $18^{\text {th }}$ Century, Alfred Marshall in the $19^{\text {th }}$ century, Ronald Coase in the $20^{\text {th }}$ century, and Elinor Ostrom in the $21^{\text {st }}$ century. From their works, the power of this field-work approach is demonstrated; and it is shown that they all essentially shared the same methodology, conditioned by time and place.

The important aspects of Coase's method, in the context of field-work, are mapped out in terms of three features. Specifically, we may say of his method that: (a) it is interdisciplinary, extending to several social sciences and to law; (b) it relies on detailed use of evidence, including number (of which accounting data are an important part), primary sources (including explicit contracts), and narrative sources (including implicit contracts, and conversations); and (c) it is methodologically humble and permissive, yet 
complex, focussing on how institutions work together to mould the economic system. It concludes by a brief consideration of the Coasean legacy, which is a study of humankind as it is, and of the economic system as it exists, all of which are facilitated by the grounding of research work in the field. The domain of the argument in this paper is economics, and specifically the micro-economics contained within it, and finally that part of it which is most significant in the present context, namely managerial and decision economics

\section{RONALD COASE AND FIELD-WORK}

To some, it seemed strange that Ronald Coase should have won the Nobel Prize in Economics in 1991. He was not a very technical economist, and his papers were not peppered with equations, and econometric estimates. He had not written all that much, in relation to much more prolific economists who had been awarded the Prize, nor did his reputation blossom initially as a Professor of Economics. Further, his key writings, on which his reputation hinged, were few in number, being essentially the two 'vintage' articles of Coase $(1937,1960)$. These seminal papers have in common the concept of transactions costs: the costs, in brief, of accessing or running markets, Klaes (2000). In the first, Coase (1937) argued that firms exist because they are relatively more costeffective than the direct use of the market: so firms economise on transactions costs. In the second, Coase (1960) argued that government intervention may arise when parties cannot agree on property rights, and/or transactions costs are too high. Both these profound papers suggest Coase must have had a prodigiously thorough training in analytical economics.

However, a fact that Coase flaunted was that he had never been trained as an economist. In the recent personal interview reported inTerjesen and Wang (2013, p. 177) Coase admitted no more than that he had 'sometimes sat in some economics classes just to get a feeling for what was going on in the field [viz. economics]'. He was what some (including him, in self-deprecation) had come to describe as an 'accidental' economist, Lyons (2013). However, to make this judgment, as almost all commentators now accept in hindsight, is to miss an essential point: which is that many of the greatest thinkers on economics were not trained in the subject, and did not regard themselves as other than 'accidental' economists. John Maynard Keynes, founder of modern macroeconomics, but also philosopher, political activist, connoisseur, biographer, and much more beside, would be an obvious example of this, Harrod (1953).

However, not so much appreciated is the route that Coase took to obtaining his fundamental insights, for example, the reason why firms exist, and the role of property rights in shaping contracting practices. This route has been used by many of the great intellectual figures of economics, but is now rather down-played, and often not taught as a method of investigation in the great universities of the world. This route is simple but hard, and involves direct observation, 'in the field', of how organizations function, and 
the roles that economic agents play in bringing about this functionality. Helper (2000), in a modern rather than historical context, identifies the following advantages of fieldwork over other methods: direct enquiry about objects and constraints; enquiry in areas devoid of theory or evidence; using the right data; and promoting intuition through images of experience. She argues that amongst the many things that field-work can do is to suggest insightful counter-examples, or modifications of received knowledge. To illustrate, piece-rates can be adopted to increase productivity. For example in a case study of a glass manufacturer, a famous paper by Lazear (2000) demonstrated a $44 \%$ increase in output per worker. However, Freeman and Kleiner (1998) found, by their field-work in a shoe manufacturing enterprise, that a move to time-rates did have advantages, in that it fostered both process and product innovation.

Helper also points out that theory construction is often prompted by new findings in the field, illustrating this by Piore's (1979) development of labour market segmentation theory, which was inspired by incidental field-work comments of respondents. These were not prompted, but were freely given by a desire to 'tell their story'. Finally, she reports how field-work has facilitated 'images of work', providing the example of how observations from the mezzanine of a factory for manufacturing auto-parts led Goldin and Katz $(1996,1998)$ to a new discovery. They found that the introduction of continuous-process technology was an innovation that was complementary to skills acquisition, rather than opposed to it. These relatively recent field-work findings are entirely on a par with Adam Smith's (1776, Ch. I.i-I.ii) insights into the division of labour from visiting nail manufacturers ('naileries') in his native town of Kirkcaldy. Fay (1956) has noted that Adam Smith (1776) himself referred explicitly to 'naileries', and their functions. Fay (1956) identified two local industrial areas, renowned for naileries that were familiar to Smith: in Pathhead on the Dunnikier estate; and in Sinclairtown on the Dysart estate. Rubin and Hooker (1965), who have specialised in the strong statistical basis of Smith's reasoning, remind us that Smith also referred to naileries in his treatment of money, where he displayed first-hand knowledge of a Scottish village which specialised in nail making, in which nails were used to pay debts in hard times.

For those who employed these field-work methods, they were in essence investigating the foundations of economics in general and, in particular, the foundations of what we would now call managerial and decision economics. As we shall argue, the foundations of economics in each of the four centuries in which the subject has been developed from its Scottish Enlightenment origins, were radically re-cast by economists like Adam Smith, Alfred Marshall, Ronald Coase, and Elinor Ostrom, all of whom took their initial inspiration from reality. Their methods included direct observations and the generation and use of primary source data, and were not just based on a priori reasoning, or secondary source data. One dimension of the argument in this paper will be that a more wide-ranging, less narrow interpretation of the mission of economics has, for each of these economists, been part and parcel of their ability to achieve remarkable innovative steps in the development of the subject. Of particular importance to this has been their 
intimate exploration, using grounded evidence, of the rationale, management, decisionmaking and functionality of the business enterprise.

In the case of Coase, in conversations recently conducted with Terjesrson and Wang (2103, p. 175), he recounted his early US field-work experience as a Sir Ernest Cassel Travelling Scholar. This was awarded to him as a fresh-faced, twenty-one years old, bachelor's graduate of the London School of Economics, and he made use of it as follows: 'I spent the academic year 1931-32 studying the structure of American industry with the aim of discovering why industries were organised in different ways'. He did this by visiting factories and businesses in person, and interviewing key personnel. This allowed him to develop the concept of transactions costs, and to use it to explain why firms were formed. He said: 'All this was achieved by the summer of 1932, as the content of a lecture delivered in Dundee in 1932 makes clear'. Coase than went on to explain that in his time in Dundee, his enthusiasm for field-work did not diminish, and that 'During this time I took my students on tours of jute factories. At the time Dundee was built on the jute industry. Jute was used to make carpets and bags', see Terjersen and Wang (2103, p. 177). After war-time work as a statistician (in the Forestry Commission and the Central Statistical Office), Coase spent nine months in the USA (in 1948) on a Rockefeller Fellowship studying the American broadcasting industry. Coase was ever the field-worker!

\section{MODES AND METHODS OF SMITH, MARSHALL, COASE AND OSTROM}

As suggested earlier, an interesting aspect of Smith, Marshall, Coase and Ostrom is that none of them was trained in economics. Smith was a moral philosopher; Marshall was a mathematician, Coase was a cost accountant, and Ostrom was a political scientist. Is there something about not being an economist by origin that makes one more willing to engage in field-work? Perhaps, as a consequence of the thorough grounding in economic reality acquired by field-work, is one reluctant to be convinced that mathematics alone (or econometrics alone) can resolve 'truths' about the economy? Maybe approaching economics from a new angle can assist in viewing the subject anew: and therefore the making of novel contributions becomes more likely.

To illustrate, Smith was in constant contact with the merchants, capitalists, politicians and bankers of his day. His analysis of the banking system of his time (Smith, 1776; Ch. II.ii) shows a remarkable grasp of contemporary economic problems arising from bank failures, and loss of confidence in banking institutions, including the relationship between the Bank of England and the commercial banks. Indeed Smith's publication of The Wealth of Nations was delayed because of his policy involvement in the banking crisis.

Marshall used mathematics as a background tool, simply to verify that informal reasoning could be thoroughly tightened by precise, consistent analysis if need be. But in the end of the day, Marshall thought you had to 'throw away the mathematics'. He 
enjoyed his meetings with businessmen, including his summer sallies into factories, workshops and other business premises, Groenewegen (1995, pp. 193-202). He was until the end of his life a commentator on the state of the British economy. His expert witness contributions to various commissions bear witness to this. Coase himself was influenced by empirical traditions in the LSE where he was trained, including the writings of Professor Sir Arnold Plant (1898-1978), see Coase (1994), and this encouraged his interest in American industrial practice, including his early (in 1931-32) field-work study of the automotive industry, and his later field-work study (in 1948) of the broadcasting industry. Ostrom came to economics from political science, and her autodidactic studies in game theory. She found the latter could illuminate some long standing mysteries about the 'tragedy' of the commons, Hardin (1968), that had so exercised Coase (1960) himself, in his partial solution to the tragedy. Her field-work was more systematic than those who went before her, as befits the evolution of practice in this area of academic endeavour over the $20^{\text {th }}$ century, cf. Piore (1979), Reid (1987, 1992), Helper (2000), Teddlie and Tashakkori (2009), Tashakkori and Teddlie (1998), Tashakkori and Teddlie (eds.) (2003).

\section{Adam Smith}

Adam Smith (1723 - 1790) was a philosopher, a literary and legal scholar, as well as, of course, the founder of 'modern economics' as we now know it, with his publication of The Wealth of Nations (1776). Economics was described then as 'political economy'. Indeed it continued to be described as such in my own undergraduate student days at Aberdeen University, a 'Scottish Ancient' University of fifteenth century foundation (1495). Political economy is a term which still has popular currency, and its use is advocated by another great child of Kirkcaldy, Fife, Dr. Gordon Brown MP, in his postPremiership volume Beyond the Crash (2010). Political economy is also enshrined in the titles of two notable journals, the Journal of Political Economy, the 'house' journal of the University of Chicago, and the Scottish Journal of Political Economy, the 'house' journal of the Scottish Economic Society. Both are inspired by the economics of Adam Smith, and in a broader sense than the term 'economics' would suggest. The connection to law \& economics remains strong with both journals, as befits a discipline which had its roots in the Lectures on Jurisprudence delivered by Adam Smith (1762) at Glasgow University, and both journals are willing to engage with policy issues like poverty, crime, sport, religion, business ethics, and so on, very much in the spirit of Adam Smith, who took the world as he saw it as his starting point, rather than starting with a set of a priori principles. As we shall see, Coase too took Adam Smith as a key reference point, and his own grounded methodology was very Smithian.

As we shall argue, 'the world as we see it' is a fundamental focus of field-workers, and the political economy perspective allows a ready appreciation of the merits of this approach, whereas the contemporary economic science approach is more cautious about the merits of field-work, or even hostile towards it. To the pure economic scientist, if 
there is a temptation to 'eat the cake' of field-work, it is largely resisted. Unlike Alice in Lewis Carrol's (1865, Ch. 1) Alice... in Wonderland, who readily falls to temptation, saying 'Well, I'll eat it... and if it makes me grow larger, I can reach the key' the economic scientist is fearful of growing larger, in an empirical sense, and rejects the key to discovery which is the field-work method. As Coase (1960, p. 43) would have it, knowing what the real situation is, before undertaking analysis, is important: 'A better approach would seem to be to start our analysis with a situation approximating that which actually exists, to examine the effects of a proposed policy change and to attempt to decide whether the new situation would be, in total, better or worse than the original. In this way, conclusions for policy would have some relevance to the actual situation'. The perspective that political economy, as opposed to economic science, allows you, is a wider vision of what the economy does, how it functions, and how it may be nurtured.

The term political economy is rather more accommodating to a broad view of economics, going beyond the quite narrow limits set on economic science by Lionel Robbins (1932) in his influential little volume on the Nature and Significance of Economic Science. This brief book became very influential for its focus narrowly on the use of scarce resources to satisfy given ends. That treatment came to personify the LSE approach to economics, in which the implied methodological underpinning is optimality: that is, of the best use of resources. Perhaps not surprisingly, Coase did not get on very well with Lionel Robbins, being more at home with faculty members like Arnold Plant, Coase (1994). In his interview with Terjesen and Wang (2013, p. 178) he said: 'My type of research was not appreciated by Lionel Robbins. When I was considering leaving the LSE for America he never talked to me. If he had, perhaps I would have stayed'. At least, if not encouraged to stay at the LSE by Robbins, Coase was apparently given a free reign in the lectures he delivered there, on Principles of Economics. Robbins' focus on choice, as the core principle of economics, which rather repelled Coase, was more profoundly evident in later incarnations of Robbins' approach, like the work of J. R. Hicks (1939), in Value and Capital which was also largely undertaken at the LSE. In that elegant book, the Walrasian framework of general equilibrium, Walras (1874), which hitherto had lacked a detailed theory of optimization at the level of the single economic agent, is, in Hicks, underpinned by rigorous theories of individual household and producer optimality, which in the former case went well beyond the allied earlier treatments by the likes of Pareto and Slutsky. The fact that Hicks' treatment in the main text of Value and Capital was almost entirely literary (and therefore highly accessible to tyro economists) but yet was backed up by rigorous mathematical proofs in Appendices which went far beyond the relatively clumsy mathematics of the likes of Marshall (1890), made its general impact all the greater, and its credibility with technically-inclined economic theorists that much the higher.

Alas, these developments in analytical microeconomics took economic science a long way from its political economy roots, and perhaps unfortunately decoupled the grounding of subsequent developments of theory on direct observation in the field, 
preferring instead to make theorising depend on a priori reasoning - essentially on postulates of rationality - rather than on behavioural observation. As Coase was more recently to observe, in his interview by Terjesen and Wang (2013, p. 183): 'economics has become a study of human choices. It has become an approach detached from the real economy. Many questions that are vital to understanding how the economy works but cannot be put into the logic of choice are inevitably ignored, including production and entrepreneurship.' He went on to say, very much along the lines of Adam Smith and Alfred Marshall, that "we believe that economics is a study of man creating wealth in society', see Terjesen and Wang (2013, p. 183).

\section{Alfred Marshall}

Alfred Marshall (1842 - 1924) was one of the first great professional economists, in that he made his living as a Cambridge University don, was the first Professor of Political Economy at Cambridge University, and practiced the full spectrum of the academic's craft: as teacher, research worker, publisher, economic policy adviser, and mentor to aspiring economists (including John Maynard Keynes, and Arthur Cecil Pigou), Arena and Quere (eds) (2003). His university education was in mathematics, in which he had displayed an early precocious talent, graduating as Second Wrangler at Cambridge University in 1865. Initially he undertook research in mathematics in Cambridge.

However, pulled away from mathematics by moral conscience, he felt he was neglecting his public duty in overlooking the sometimes shameful conditions of economic disadvantage that he had witnessed in the streets of the major cities of Great Britain, and thus turned to economics, Groenewegen (1995). Initially, he read David Ricardo and John Stewart Mill, and tried to turn the (narrative) economic logic of Ricardo and Mill into mathematics: with some success. As this interest developed and matured, he became more interested in evidence, and tried to blend both direct field-work observations with historical evidence in creating his key works of economic analysis, including his most famous work, the Principles (1890). His other important works in this mould include Industry and Trade (1919), which is worthy of particular attention, as it displays such intimate knowledge of real business conditions, connected by a clear analytical approach, as to lay the foundations of managerial and decision economics as we know it today. In this work the subject matter extends from products, technologies, and pricing, to management, marketing, and labour relations, all of which Marshall understood well, from both a grounded, field-work perspective, and from an economic modelling perspective. Marshall (1919, p. vii), in his Preface to Industry and Trade, is very explicit about the importance of field-work to the development of this thought, saying: 'Nearly half a century has passed since I set myself to obtain some insight into industrial problems by obtaining leave to visit one or more representative works in each chief industry. I wanted to obtain a sufficient knowledge of mechanical technique...to understand the resources and the mode of operation of all elementary plant in general use'. Here, he is very precise in indicating, first, that he went into the field to obtain 
evidence, second, that he sought a representative sample of industries in doing so, and third, that one focus of investigation was on mode of production, echoing the later enthusiasm of Coase - see Coase (1972), Coase (1992), Coase and Wang (2011) - for a better understanding of 'the industrial structure of production'. I say 'one focus' because production was not Marshall's only field-work concern. Another focus was on conduct, be it represented as habitual and conventional or deliberative and calculative. The following quote from Marshall and Marshall (1896, p. 37), taken from his Economics of Industry (2nd Edition) suggests a fundamental motivation, and rationale, for his field-work: 'Nobody's actions are all governed by careful calculation; in fact even the most deliberate persons are much under the influence of habit and impulse. But on the other hand habit itself is largely based on deliberate choice: and further the side of life with which economics is specially [sic] concerned is that in which man's conduct is most deliberate, and in which he most often reckons up the advantages and disadvantages of any particular action before he enters on it. It is that side of his life in which, when he does follow habit and custom and proceed for the moment without calculation, the habits and customs themselves are most nearly sure to have proceeded from closely watching the advantages and disadvantages of different courses of conduct'. This suggests that Marshall's frequent focus of attention in the field is on observed actions or 'courses of conduct'. These may appear to be merely habitual at a superficial level, but, if one drills-down into reality, often are found to be based on deliberate calculation, involving the balancing of advantage over disadvantage. Here, Marshall is not embracing an approach which Robbins (1932) and his followers were later to espouse, that economics was essentially a theory of a priori choice, but rather seeking an understanding of actually observed human conduct. This may presents itself to us in the field as a mix of habitual and calculative action. Yet what might be called 'the eventually habitual' is probably initially grounded on a personal, judicious balancing of advantage and disadvantage, which, once completed, may subsequently resolve into conventional behaviour. To Marshall, this 'balancing' is not to be taken as an a priori principle of rationality, but as a behavioural characteristic which can be investigated in the field. As Hart (2012) has recently commented and elaborated, Marshall did have a highly developed view of the actions of the mind, and of how decisions were made. Arguably his notion of 'balancing' was far from crude, but rather an attempt to interpret conduct in the context of the real world, in which most decisions are a mix of the habitual or conventional (a practice that cuts through complexity and reduces problems to simpler elements) and fresh analysis and interpretation (which 'customises' habit and convention to the specific new circumstances the decision-maker faces), see Marchionatti (2003) for further research on this.

It is true that some of the knowledge displayed in key works of Marshall is 'secondhand', in that it is based on secondary sources, especially in the case of historical evidence. But the most important aspects of Marshall's business, commercial and 
industrial knowledge were acquired by direct observation, and by primary source data acquisition and generation. As Hart (2012, p. 16) has pointed out, at the time of Marshall's development as an economist, there was an increasing focus on observation and fact gathering, as being the more reliable basis for scientific advance than the use of intuition or hypothesising in a priori terms, using pure theory. In a letter to his contemporary Neville Keynes, Marshall said that 'the right order is first to emphasize the mutual dependence of induction and deduction, \& afterwards to show what kinds of enquiry the economist has to spend the greater part of his time in collecting, arranging and narrating facts, \& in what kinds he is chiefly occupied in reasoning about them \& trying to evolve general processes of analysis and general theories', Whitaker (1996). Perhaps from this methodological stance too arose his powerful intuition about economic magnitudes, and their causes and effects, to the extent that he could confidently conjecture plausible values for economic magnitudes of new theoretical concepts (e.g. elasticity of demand), without the benefit of today's econometric methods.

In a way that, many years later, was remarkably to resemble Ronald Coase's experience, Alfred Marshall's greatest field-work influence was a visit to the United States of America (in 1875 for four months), see Groenewegen (1995, pp. 193-203). He subsequently wrote about that experience in a paper entitled 'American Industry', which Marshall (1875) read to the Cambridge Moral Sciences Club in that same year. He wrote a related work ('The Economic Condition of America'), which Marshall (1878) read to a public audience in Bristol. By this time, he was Principal of the Cambridge University offshoot, University College Bristol, which was later to become Bristol University. Subsequently to his US visit, Marshall made a point of devoting at least some time over the summer recess from Cambridge University duties to visiting British businesses: typically a mixture of large (e.g. major potteries in Staffordshire), and small (e.g. toolmakers in Wolverhampton) businesses, Groenewegen (1995, 208-214). He would engage the owner manager in discussion of all aspects of his trade, and was fond of guessing key features of the business, given what he had observed during his visit. For example, he liked to guess what wages were being paid, and Marshall was delighted at his own accuracy, writing that 'my error did not often exceed two shillings a week on one side or another', see Pigou ed. (1925, pp. 358-9).

However, when it came to the population of firms, Marshall did not confine himself to the small firm, which in the $19^{\text {th }}$ century was overwhelmingly the predominant firm type, and the one he seemed to have most in mind in his Principles. But, rather, he talked of the whole 'size distribution' of firms (as we would now put it) from the least to the greatest. He was familiar with everything from small firms to monopolies, both in theory and by direct observation, and had a good theory for each, but (arguably) no complete new theory of the territory in between (viz. oligopoly - 'competition among the few', Fellner, 1960), though modern interpreters, like Loasby (1978) have discerned a proto-version of a modern information-based theory in the Marshallian 
theory of the firm. Whatever his focus, be it small business of big business, Marshall was firm in his methodological approach, which aimed to combine fact and theory. It was a way which was subsequently to be very attractive to Coase. In his reflective piece on the old and new generation of economists, Marshall (1897, p. 133) defined economics in a fashion that Coase, undertaking path-breaking research some thirty, forty or fifty years later, would have entirely endorsed: "the true inductive study of economics is the search for an arrangement of facts with a view to discovering the ideas... which underlie them: and ...the true analytical study of economics is the search for ideas latent in the facts...brought together ..by the observer of contemporary life'. Although, until recently, some would be surprised at the characterisation of Marshall as 'the observer of contemporary life' in his field-work capacity, modern opinion is now very supportive of this latter view, first detailed in Groenewegen (1995, Ch. 7). Beccatini (2011, pp. 1-3) has pointed out, in his detailed treatment of Marshall's 'industrial field-work', that the lack of abundant documentary evidence should not blind us to its significance. Rather, Beccatini (2011, p. 3) argues it would be wrong for one to characterise Marshall's methods as 'not properly scientific and even impressionistic'. Instead, one should understand that what Beccatini (2011, p. 4) calls the 'far reaching theoretical changes' evident in the Marshalls' Economics of Industry were inspired in large part by systematic and repeated field-work, to which Marshall's wife and coauthor Mary Paley Marshall could bear witness, see M. P. Marshall (1947, pp. 42-43). Its nature was indeed the 'intensive, direct, exploration of British manufactures', Beccatini (2011, p. 4)

\section{Ronald Coase}

Ronald Coase (1910-2013) is one of the greatest economists of all time, and certainly a serious candidate for the greatest economist of the $20^{\text {th }}$ century. He will forever be associated with his discovering and clarifying the concepts of transaction costs and property rights, and their implications for organizational form and institutional development, in the context of a market mediated economy.

We know that the empirical basis of the greatest contributions of Coase $(1937,1960)$ were the field-work visits he undertook in the USA in 1931-32. Coase (1992) recounted how he studied US industries, by on-site visits to, and interviews of, firms, his aim being to discover why they were organized in such diverse ways. Though this did not make possible a completely new approach to economics at the time, it did lay the necessary foundations of what was to become known as the transactions cost approach to economics, Commons (1931), Coase (1937, 1960), Williamson (1981), Cheung (1998), Benham and Benham (2001). Thus Coase (1992) says: 'What came out of my enquiries was not a complete theory answering the questions with which I started but the introduction of a new concept into economic analysis, transaction costs, and an 
explanation of why there are firms.' This development of the concepts of transactions costs, and the rationale of the firm, were achieved in 1932, and laid the basis for his path-breaking article on 'The Nature of the Firm', published in the LSE research journal Economica in 1937. It was very favourably cited by the Royal Swedish Academy of Sciences in awarding Coase the 1991 Alfred Nobel Memorial Prize in Economic Sciences.

Though all four economists discussed in this paper were long lived, in the context of their times and tides, Coase has excelled them all. He has been an economist of remarkable longevity, and quite astonishing fecundity into old age. Keynes (1924, p. 372) in his beautiful obituary notice of Alfred Marshall in the Economic Journal wrote of his later years that because of 'loss of memory and great feebleness' Marshall 'struggled to piece together one more volume', ending sadly 'though, as of old, he would sit and write, no advance was possible'. Personally, I well remember Ronald Coase at this comparable age being a spry octogenarian, with a tenacious ability to pin down an argument, and to do the detailed research required to put it into a scholarly form that would be accepted by his peers. Further, he was able to back up this written authority with a cultured ability to 'mix it' in a seminar or conference setting, when the arguments were speeding along briskly, and temperatures were (on occasion) somewhat raised. His calm never left him, and his patient lucidity almost invariably won through. It took an intellect of great strength to produce at the age of ninety nine (with Ning Wang) a book that instantly became a best seller world-wide on How China Became Capitalist, Coase and Wang (2012). One factor that led to the popularity of this book was its extensive reliance on primary sources. Coase and Wang (2012) align this proclivity with the cultural predisposition of Chinese analysts to use the approach of 'seeking truth from fact': to use what we would call in this article a 'grounded' approach to economic and institutional analysis. Though the groundwork was undertaken by Professsor Wang, who 'provided information about events in China and their interpretation' the development of arguments and the signalling of their relevance and significance, is a joint work, presenting a 'final product' which 'is the result of close cooperation', Coase and Wang (2012, p. xi).

Although Coase was a scholarly in his conduct of field-work, and drawing conclusions from it, not all have agreed with his findings. Perhaps pre-eminently, Benjamin Klein (1988), one of the economists to have done most to extend the compass of Coase's analysis of vertical integration, has also engaged in a dispute that generated great attention, and not always to the advantage of Coase's reputation. The advance of Coase's methodology was perhaps marred by this dispute with Klein over the breadth of the notion of transactions costs. Klein (1988) viewed Coase as narrowly restricting transactions costs to the price of the contract, and the cost of writing the contract, which he called, rather disparagingly, 'ink costs'. Rather, Klein would focus attention on holdup costs as having a significant role in precipitating vertical integration. By contrast, Coase excluded holdup effects from his analysis, because his view was that 
such problems were usually solved by contract design and reputational capital. In this context, Coase (2006, p. 267) referred specifically to his early field-work evidence when he wrote that in 1932 the Chief Executive of General Motors had told him that he had vertically integrated with Fisher Body 'to make sure that their body plants were adjacent to GM assembly plants'. Taken at face value, this is a rather sparse account of the motivation behind vertical integration. Klein, by contrast, judged that holdup costs were more important than Coase's 'ink costs', in explaining vertical integration, and specifically that these costs were in more play in the GM-Fisher case than Coase had admitted. Such costs arise from the compensation required to cover the risk of postinvestment holdup after the vertical integration has been implemented. Though much has been written on this dispute, see Wright (2007), the discovery by Klein (2007) of some important primary source contracting evidence on Fisher Body has definitely swung the argument in Klein's favour. We note that much of Klein's work on contracts would argue that reputational capital can resolve hold-up issues.

\section{Elinor Ostrom}

Elinor Ostrom (1933 - 2012) was the first woman to be awarded the Nobel Prize (2009) in economics. She graduated BA, MA and $\mathrm{PhD}$ from the University of California Los Angeles, with all three degrees being in political science, rather than in economics. In this she had common ground with Smith, Marshall and Coase, in not being formally trained in economics. Another broad common factor is that she largely favoured 'little government' rather than 'big government', and was especially influenced by the writings of Hayek (1944) and Buchanan (1968) in this respect. This also meant that she embraced, and contributed to, the emerging new institutional economics and the approach to public economics that this implied, Ostrom (1986). In this context, she developed a new approach to development and institutions, Ostrom (2011). This approach combined game theory, the meta-analysis of many case studies that were founded on field-work, and laboratory testing, from which she was able to discover that by allowing communications or 'cheap talk' there was a reduction of the overharvesting of common pool resources. A final, different kind of common factor, but nevertheless a shared one with Coase specifically, was that significant portions of the economics establishment were taken aback when Ostrom won the Nobel Prize for Economics (2009). Reasons for this would include her political science background, her general espousal of political economy over mathematical economics, her willingness to engage in inter-disciplinary work, and no doubt her advocacy of field-work methods in economics.

In fact Ostrom's credentials in mainstream economics are impeccable, as for Smith, Marshall, and Coase. She has been published in the major economics research journals, and is widely and favourably cited by leading economists. Though not unwilling to see a role for regulation (as with Marshall, Smith and Coase), she extended the scope of feasible non-regulation to an area that seemed, at first sight, to highlight the immovable 
deficiencies of the market in permitting efficient and sustainable access to 'the commons' i.e. goods (including common pool resources, like fishing, forestry and mineral resources) which are rivalrous, yet non-exclusive. In fact, she found that individuals, left to their own devices, and with no intervention, have traditionally devised clever long-term solutions to what Hardin (1968), in great disillusion, had called 'the tragedy of the commons': implying by the term 'tragedy' that it was beyond solution by the spontaneous actions of economic agents. And finally, most important for this paper, she was an inveterate field-worker, who always predicated her theorising on direct observation of economic reality, either by herself or by others. In her case, this field-work evidence was drawn from such varied locations as Nepal, Indonesia, Japan and Switzerland, though not excluding her own United States (and specifically California). One of her most noted investigations utilising field-work evidence was of communal grazing of meadows by cattle in a Swiss canton, Ostrom (1990, Ch. 3). Economic analysis of the traditional kind would predict over-grazing of the common resource. However, what Ostrom discovered was that consensual rules in the community, which had evolved over the centuries, mitigated this effect. In this case, from the early sixteenth century, regulation of the meadows by common consent had been achieved so effectively that over-grazing had been almost entirely prevented. This effect was not just Swiss or European, but was discovered to pertain in diverse cultures and topographies: in Kenya, Turkey, Nepal, Guatemala, and even in California. On the basis of such findings, Ostrom (1990) was able to formulate eight rules for effective governance of the commons. These included low-cost conflict resolution, and the monitoring of member's behaviour by the group. This has led Fennell (2011) to talk of Ostrom's Law, namely that 'a resource management system that works in practice can work in theory'. Here we have sharply illustrated in the work of Ostrom the role of induction, based on field-work; which amount to a reversal of the primacy of theory over evidence that is so common in economics today. A new role for theory, when confronted with efficient practice, is to help us to model this practice, and thus to help us to explain, or to provide a rationale for, what happens in practice. Ostrom did not start with theory, but with evidence. Not averse to using abstract theorising, she then used game theory to help us understand the evidence, Ostrom (1990, Ch. 1). Finally, she closed the scientific loop by using experimental methods, with human subjects, to test theory in the laboratory, see Walker, Gardner and Ostrom (1990) and Janssen, Holahan, Lee, Ostrom (2010).

The Economist blog (June $30^{\text {th }} 2012$ ), in its obituary notice of Ostrom reported that 'Pure economists looked askance at this perky, untidy figure, especially when she became the first woman to win a shared Nobel prize for economics in 2009', which reflects no credit on the narrow mindedness of some sections of the elite in academic economics. However, a somewhat similar reaction had been apparent when Coase received the Nobel Prize in 1991. The obituary goes on to add, that despite being aware of this negative criticism Ostrom 'was not put out'. Indeed, she rose above it. In this, 
she shared the fortitude and longevity of Smith, Marshall and Coase, who were courteous in the face of criticism, and unashamed of seeming 'out of fashion', if they thought the fashion to be just a fad, from which there would be an ultimate reversion to common sense.

\section{THE CONTRIBUTIONS OF COASE}

This latter part of the paper is developed by asking three questions, from the perspective of Coase, about economists, and specifically managerial economists. First, what do we $d o$ ? Specifically, what are the boundaries of our discipline? Second, how do we do it? That is, what are their methods? And, third, what do we get from within the boundaries we set and the methods we use? In the eyes of Coase, we get an approach that puts institutional structure ahead of a priori principles.

What do we do? A key issue to explore in this context is: what are the boundaries of the subject of economics? An immediate corollary of this is: why are such limits set to our activities as economists? An aspect to be pursued in detail, of what we do as economists, is the extent to which we embrace inter-disciplinary studies. Here, we shall enquire whether economics will go on to 'invade' other disciplines, or whether its boundaries are in a sense self-limiting. We shall see that, in Coasean terms, our boundaries are themselves determined by one of the central objects of economic analysis, namely the forces of competition.

How do we do it? Here, the focus is on methodology: the grounded, inductive approach, which does not ignore the use of analysis, but does not necessarily endorse its form being mathematical. It holds that the key principles of economics are simple, and have endured from its roots, through from Adam Smith, via Alfred Marshall to the present. Mathematical embellishment often creates an illusion of progress, but in reality it is throwing out important substantive problems and instead showcasing minutiae, which are argued out - often bitterly - in academic journals (e.g. what do we mean by the efficient markets hypothesis?). These disputes often miss or neglect the key point which is the quest for understanding reality. Coases's most important substantive contributions to economic analysis, transactions costs and the assigning of property rights, have been largely ignored by the great volume of mathematical economics that has been developed in economics from the 1930s onwards. Indeed, it remains true that Coasean concepts are quite difficult to incorporate into mathematical economics, as they are, to a fair extent, empirically and institutionally driven concepts. What I suggest below is that how we do it, from a Coasean perspective, but also consistent with the other three other great figures we are profiling, is best summarised by saying we used a 'mixed method' that combines qualitative and quantitative evidence, Teddlie and Tashakkori (2009). This is not to side-line the primacy of field-work observation to his original contribution, but more to emphasise that the use of various forms of primary 
source evidence are corroborative of his desire to observe, measure, then analyse, rather than to conjecture, model then analyse.

What do we get? Put another way: where does all this take us? A simple answer might be: to the new institutional economics. However, Coase himself is reluctant to be categorised as narrowly as this. Rather he is asserting a continuity of approach in his own method, which he particularly identifies with Adam Smith and Alfred Marshall, and to which, it could be argued, might be included Elinor Ostrom, as at least one exemplar of the best in modern political economy that does largely embrace Coasean thought. That means taking the economic reality of the day as our starting point, including all its key institutional features, rather than starting from a priori principles, like optimization. The preferred alternative to optimization favoured by Coase is a more behavioural one, of the pursuit of economic self-interest, as expounded in different but largely mutually consistent ways, by Adam Smith in his treatment of the merchant's drive to self-improvement, and by Alfred Marshall in his outlining of how economics is concerned with man's actions in the ordinary business of life. The way in which analysis progresses is then partly (even largely) driven by evidence. To embrace this approach is to advocate, amongst other matters, a more elevated status for : (a) legal practice and other institutions as a governing framework; (b) accounting data, and other primary sources, as evidence; and (c) the pursuit of the methodological goal of operational insight, and its application to problems of economic policy, rather than of hypothesis testing in a logical positivist fashion, Popper (1959). Here, we cannot roll out full arguments, but choose to give three illustrative examples, under the three headings of: what we do; how we do it; and what we get.

\section{What do we do? An Example: Using Inter-disciplinarity}

As an economist, Coase himself played a huge role in fostering the inter-disciplinary subject of law and economics, and he has had significant scholarly and research insights into economic methodology, the history of political economy and business history, amongst several non-core areas of economics. Given this, one might expect him to lean to the view that economists would extend their boundaries incessantly, and essentially 'invade' other disciplines. Rather, Coase (1978) seemed to take the opposite view, in his remarkable paper in the Journal of Legal Studies, and argued that economics as a core discipline was actually in the process of narrowing in scope. Yet, he admitted too that there was an observed tendency for economists to engage in interdisciplinary studies across the range of social sciences (e.g. economic history, sociology, political science, international relations) and even across more distant disciplines (e.g. medicine, transport, health care, religion, defence, performing arts). To the casual observer, this apparent observation of simultaneous evidence for both convergence and divergence may seem contradictory. Yet Coase (1978) argues that this apparent contradiction can be resolved. His argument is labyrinthine in its execution, but very simple (and 
quintessentially Coasean) in its conclusion: it is that competition resolves the contradiction.

At the root of his argument is the scope of economics itself, which is dealt with more generally in this article under the heading of What do we get? To put it more briefly here in this section, Coase (1987, p. 204) would hold that what binds a discipline together into an integral whole is the existence of shared techniques, theories and subject matter. To him, in the case of economics, it has been the assured mastery of certain techniques (e.g. econometrics) and theories (e.g. rational expectations) which has allowed economists to make rapid inroads into neighbouring, or even more distant disciplines, at least in the short run. However, in the long run, it is the subject matter itself (e.g. its institutions, like banks; and its metric, like money) that binds economists together as professionals. Thus the impact of subject matter is to consolidate, rather than to extend the scope of economics as a discipline, in the long run.

Referring to a period when operational research techniques were becoming partly the province of economists, cf. Dorfman, Samuelson and Solow (1958), Coase illustrated his argument by reference to linear programming, which is both a theory (of optimization) and a technique (for computing optima). His key argument is that competition amongst academics will limit the ability of the economist to continue to invade neighbouring or distant fields. Thus economists may prove the usefulness of a technique such as linear programming for other areas, where here he cites nutrition and oil refinery engineering, though more obvious examples are perhaps defence and health care, but incumbent academics in these areas will themselves embrace and acquire the techniques and theories of economists, displacing those who temporarily invade their discipline. In this case, it is interesting to make the contemporary observation that Coase is exactly correct. Dorfman, Samuelson and Solow's influential Linear Programming and Economics Analysis is now (2014) catalogued by its publisher under 'Dover Books on Mathematics': the economists have been repelled!

Coase developed this argument further by reference to other techniques and theories, including quantitative methods (technique alone), and cost benefit analysis (both technique and theory). On his own patch of the University of Chicago, he found it more difficult to rebut the approach of the likes of Gary Becker (1976), who has argued that economic theory could take over the social sciences (e.g. political science, international relations). In defence of his own position, Coase quoted with approval Marshall's (1890) definition of economics as 'a study of man's actions in the ordinary business of life'. This emphasises that what economists do is to study particular forms of activity. Crystalizing this, Coase (1978, pp. 206-7) said, more directly than perhaps even Marshall would have dared to contemplate: 'What economists study is the working of the social institutions which bind together the economic system'. He does not say the economic institutions that bind together the economy, or the social institutions that bind together economists, so the words are very carefully chosen. This careful 
characterisation of what economists do is used by Coase to make a strong contrast with the approach of Robbins (1932), who focussed on the analysis of 'ends and means' as the defining character of economic science. Coase says that while regarding economics as 'the science of human choice' might seem to make it capable of invading any other social science, as proposed by Becker for example, this position underestimates the forces of competition which will set in motion actions that will thwart invading economists. As Coase (1978, p. 207) put it more playfully: when the King of England claimed also to be the King of France, this statement was not well received in Paris! Less metaphorically, Coase is saying that different institutional settings will provide ultimately impenetrable barriers to economist invading other disciplines.

Moving to an example closer to his heart, namely law and economics, Coase admits that economic reasoning has indeed made inroads into law, but that their adoption by incumbent academics in law has effectively competed away the ability of economists to invade further the law. They are forced out by the competition of those legal experts who are now equally skilled in key economic techniques, but also more skilled at law and its institutions than are economists. Coase does envisage an enlarged role for economists, including collaboration with other social sciences, but not an invasion. Thus, the focus of economists on the working of the economic system, with its defining metric of money, will remain their exclusive province. He predicted that the study of the impact of other social systems on the working of the economic system per se, will be one of the key ways in which economics will enlarge as a discipline, and not through new techniques and theories. Naturally, he cites the legal system as a major influence on the economic system and its analysts, and because of its focus on subject matter, rather than technique, its impact on enlarging economics is likely to be permanent.

\section{How do we do it? An Example: Using Accounting Evidence}

When it comes to the use of evidence, as well as espousing the explicit field-work method which has been referred to in the earlier part of this paper, Coase was an advocate of what we would today call the 'mixed method', see: Tashakkori and Teddlie (eds.) (2003) Tashakkori and Teddlie (1998), Teddlie and Tashakkori (2009) for a wide ranging set of illustrations of this approach; and Reid $(1993,2007)$ and Reid, Jacobsen and Anderson (1993) for applications of these method to small business enterprise and strategy. It combines both qualitative and quantitative methods, but has field-work as a central inductive element. Its aim is to make the best use possible of all potential evidence of relevance to the problem at hand. In this sense, the approach of Coase to a problem may be characterised as forensic: no form of evidence is rejected provided it helps to inform the enquiry. Though unsympathetic to econometric and mathematical economics methods, for good reasons (essentially their neglect of reality), Coase did have a highly quantitative bent of mind, and like Smith, Marshall and Ostrom was very familiar with the quantitative fine-detail of economic practice, in terms of fact and number, and their bearing on how businesses functioned in an operational sense. 
Although Coase, as observed above, had had no formal training in economics, acquiring the necessary skills through his mentors like Arnold Plant, he did pursue a commerce degree at the LSE, which fine-tuned his quantitative perceptions and judgments. The syllabus of that degree included courses on factory accounting and cost accounting (effectively training him in what we would now call management accounting) and in financial accounting, Coase (1990). It was another influential LSE mentor, Ronald Edwards, who stimulated Coase to consider accounting data as a valuable resource for economic research. In doing so, Coase was both enthusiastic, and embraced the use of accounting evidence, but at the same time critical, in that, for example, he challenged the wisdom of accountants who would cavalierly add together disparate items in order to facilitate the aggregation of distinct company accounts. As Coase (1990, p. 4) himself put it, he was intent 'to show economists what could be done, and accountants what should be done'.

Coase's approach was exemplified by his heavy involvement in the report on The Iron and Steel Industry, 1920-1935: An Investigation Based on the Accounts of Public Companies (Special Memorandum 49 of the London and Cambridge Economic Service). He recalled humorously that in those pre-computing days, his calculations were carried out using pencil and paper and a Monroe hand calculator! Whilst this report had limitations, it did show the potential value of accounting for economic research. The evidence adduced in the report was used to refute the widely held belief of many influential economists at the time that bank credit played a major role in intensifying the business cycle, especially in capital goods industries. In fact, the results of the report demonstrated that as the depression advanced from 1929 onwards, that after a brief fall, bank advances to the iron and steel industry had actually risen - until by 1935 and 1936, once profits had recovered, bank credit fell again. In other words, bank credit had a cushioning or dampening effect, not an exacerbating effect, as held by orthodox economic opinion.

From this experience, Coase (1990, p. 2) concluded that not only were accounts a valuable source of data on the conduct and behaviour of the business enterprise, but also an inspiration for developing a theory of the firm. Indeed, he went so far as to argue that the accounting system of a business is part and parcel of the theory of the firm. At the time of this retrospective vignette of the past, Coase (1990) concluded by wishing that the joint accounting and economics agenda should be progressive. That has indeed been the case, and this is one of the greatest of inter-disciplinary triumphs. To illustrate, the Journal of Accounting and Economics, which historically is largely edited out of the University of Rochester, is one of the highest ranked academic research journals, independently in both the disciplines of economics and of accounting.

What do we get? An Example: the Methodological Stance 
We have hinted that Coase's elevation to the status of Nobel Laureate did not meet with undimmed approval. One might expect this reluctance to give credit where credit is due was an aspect of alternative schools, such as the rational expectations theorists. In fact one of the most fully articulated critiques of Coase, this time from a methodological point of view, came from a central figure in Coase's own core discipline of law \& economics, namely Richard Posner. In commenting on Coase's award of the Nobel Prize in Economics, Posner (1993) was both kind and congratulatory, whilst also being severely critical of Coase's methodological stance.

What might have seemed a minor difference of academic opinion, became instead an apparently a full scale attack on Coase. Posner's (1993) three-pronged attack was launched with zeal. His trenchant critique was built on three pillars: defending the market against economic theory; Englishness; and the economy $v s$. economics. At root, Posner was offended that Coase (1977, p. 325) had expressed the view that 'our approach is inferior to that of Adam Smith', contrasting contemporary technical trends in economics (including mathematical and econometric modelling), with the political economy tradition of Smith, which espoused a more grounded approach, and an engagement with economic policy controversy and formulation. Coase had a predilection for referring to the works of Adam Smith and Alfred Marshall, and it was on these that Posner (1993) himself focussed.

Thus, Posner (1993, p. 199), in writing in terms of 'markets against economic theory', argues that Coase is 'suspicious of econometrics, just as he is of mathematical economics'. For the peculiar crime of 'Englishness', which Posner (1993, p. 204) himself admitted would 'risk startling the reader', Posner would claim that this had 'deeper significance' because it meant that Coase was heavily wedded to the writings of Smith and Marshall, as introduced to him by his most important mentor at the London School of Economics (LSE), as a student and young lecturer, namely Arnold Plant. One puts aside for the moment the identification of Adam Smith, cornerstone of the Scottish Enlightenment, as being quintessentially English! Posner too is peculiar in stating that the mathematical and econometric approaches to economics are 'primarily American', for the reality is that these approaches were pioneered, and readily embraced, in Western Europe. For example, Jan Tinbergen the Dutch econometrician was the first recipient of the Nobel Prize in Economics in 1969, jointly with the Norwegian mathematical economist Ragnar Frisch.

What Coase actually advocated was not an anti-theoretical or anti-empirical approach to economics, but the use of what he called humbly, 'simple theory'. This is a type of theory that is not over-developed by mathematics. The latter can be accused of giving theory an appearance of generality, but one which is superficial, with a reality that is often the reverse of its appearance. In talking of 'simple theory' Coase is arguing for robust multi-purpose analytical tools, but certainly not for naivety. As Posner himself notes, Coase's own 'simple theory' (be it theory of the firm or theory of property rights) 
is in fact deep and counter-intuitive. What Posner is less able to accept is that the virtue of this simple (yet sophisticated) theory is that it is a relatively universal tool, which can cast light in many a darkened empirical corner. Further, in doing so, its analytical goals are more solidly accomplished, in a way that fragile mathematical models, based on narrow assumptions, cannot permit.

Finally, under the heading of the economy vs economics, Posner (1993, p.206) is critical of Coase favouring just simple economic tools (that might even exclude optimization and equilibrium), and puts this predilection down to the 'English mistrust of abstraction'. Posner (1993, P.206) rightly observes that Coase's approach is that: 'He is interested in observable reality'. Thus the relevant form this reality takes is displayed in overt economic practices, and in institutions which can be analysed and compared: like forms of evidence before a detective analysing a crime scene, or a lawyer crossexamining in court. In Posner's (1993, p.206) own words, Coase's ambitions are humble and simply amount to 'case studies guided by basic economic theory'. This does capture key aspects of how Coase encourages us to proceed. However, it rather understates the capacity for it to embrace complexity, and to ground analysis in reality. These are the strong methodological foundations implicit in Coase's method. I suspect the riposte by Coase would be 'humble, yes, but at least robust and reliable'. These robust and reliable foundations allow Coase (1978, p.206) to claim validly, and again modestly, that economics is simply about 'the workings of the social institutions which bring together the economic systems', which very much echoes Alfred Marshall. Such institutions include firms, markets, bankers, trades unions and so on. The economist is then defined by this intense interest in these institutions.

\section{THE LEGACY OF COASE}

In the limited compass of this article, themed on field research in business, it would not be possible to cover extensively the complete legacy of Coase. However, there are influences that apply to managerial economics in particular, which are both important and far reaching. These influences include classical and neo-classical political economy, the inductive approach, the relevance of policy, and the use of field-work methods in business. Coase's discontent with the emerging methodologies of economics in his lifetime was deep-seated. Already, forty years ago, for example, Coase (1972, p. 64), in his address to the National Bureau of Economic Research on 'industrial organization - a proposal for research', was bemoaning the lack of understanding of reality present in the emerging 'new' industrial organization, saying such research was 'very narrow' and was 'appallingly ignorant about the forces which determine the organization of industry'. Nearly twenty years later, in his Nobel Prize address, Coase (1991) had still not warmed to developments, and said there was too much 'blackboard economics' in which 'the firm and the market appear by name but they lack any substance'. In that same address, he also concluded that if what a scholar said was false he would 'soon be exposed', but if what he said was true, he could count upon it being finally accepted 'if 
only he lives long enough'! He did indeed live long enough to see his ideas accepted, but I think not necessarily the methodology accepted which lay behind the genesis of his ideas.

Towards the end of his life, Coase reflected on the genesis of his famous Economica paper on the nature of the firm, Coase (1937), and did so in very Marshallian terms, saying of his first episode of field-work in the USA: 'During this time I asked people about their work, their jobs, their decisions and how they make these decisions', as reported in Terjesen and Wang (2013). The simplicity of his self-expression is palpable, and shows admirable humility. The terms and the tones are Marshallian, and this is no accident, as has been argued above. They are also, very exactly, the words which identify what the object of analysis continues to be, to this day, for those of us who work in managerial and decision economics (viz. 'work', 'jobs', 'people' and 'decisions').

In his last days, Coase was an academic advocate for a new journal Man and the Economy, see his interview in Terjesen and Wang (2013, p. 178). Of this endeavour, he said he was 'trying to get people to think seriously' - with the implication that they were not doing so at the moment. What, therefore, were we getting wrong? Coase then went on to say (p. 179) that 'economics has been static and theory driven for too long. We have to change it. The best way, as I see it, starts with man as he is [cf. Alfred Marshall] and the economic system as it actually exists in the real world [i.e. in the field]'. Of late, critics of Coase are becoming more overt. For example, some would pour scorn on his Marshallian overtones. To illustrate, from the direction of the business community, John Hagal, Director of the Deloitte Center for the Edge, in his review of the popular work The Elastic Enterprise by Vitalari and Shaugnessy (2012), is so blunt as to argue that Coase's work is 'obsolete' as he perceives that there should be a new focus on firms as learning organizations rather than (as he would put it) efficiency seeking organizations. This fails to grasp the fact that Coase's method is precisely to examine 'man as he is and the economic system as it actually exists': it does not neglect developments in organizational form, but rather embraces them, and if the learning firm is a reality, it will become part of received knowledge and practice. From a different perspective, that of an academic researcher, Dan Usher (1998), in a paper that has enjoyed about a million views on the internet, has argued that the Coase Theorem, which was not so-named by Coase himself but is derived from the famous paper of Coase (1960) on the problem of social costs, is - as Usher would put it pungently 'tautological, incoherent or wrong'. Others too have held this critical view, often in slightly different forms, including Ellickson (1991), and Cooter (1988). However, what they have in common is dissatisfaction with the modern construction of the Coase Theorem, as in Posner's (1993) work for example, but not with Coase and his works per se. The problem is with Coaseans, not Coase. Usher (1998, p. 10) himself concedes that there is an acceptable face of the artificial construction that is the 'Coase Theorem', namely that 'the economy runs on a mixture of price-taking and deal-making and 
...bargaining is no free good', which is indeed, as he would put it, 'instructive'. Alas, though Usher's paper has had almost a million views, it has been cited by just 71 people.

\section{CONCLUSION}

Today, the use of field-work methods in economics is becoming more acceptable. The work of Coase and Ostrom has been influential in bringing this about, and earlier the foundations of Smith and Marshall made their attitudes of mind possible. Economists in business and management schools are now particularly open to new forms of evidence, including: business history e.g. Helper (1991); case studies; experimental methods; and field-work generated evidence and insights. There is some appetite for field-work by economists, especially if economists collaborate with other specialists, and publish in non-economics or inter-disciplinary journals. Development economics and the economics of organization have particularly benefitted from this welcome trend. Susan Helper, mentioned several times in this article, is an economist who has shown a commitment to field-work methods. She was involved with an NBER-Sloan project, under the leadership of Martin Feldstein (2000) which instituted so-called 'pin factory' visits, inspired by the early work of Adam Smith. This involved interviews with business people and practitioners, and led to new insight into the role of information technology in productivity advance. However, core economics, which is now much more theoretical and econometric than two generations ago, remains largely antithetic to field-work and case study work. Sadly, field-work training is rarely a part of graduate training for economists, and it often remains difficult to publish in mainstream economics research journals if your paper is field-work based.

As a final comment, this paper has noted how Coase revolutionised how we think of economics, and more generally political economy. The field-work method that he adopted can be put to use in many parts of social sciences, and of economics in particular. For example, Alan Blinder (1991) looked at the microeconomic foundations of macroeconomics in his study of price stickiness, using interview data with price setters. At the time, he admitted that his approach used a 'rather unorthodox (for economists) methodology'. However, it did provide insight that would have been hard to find by any other means: for example that price setting typically took place annually, and lagged one quarter behind a demand or cost shock. Within economics, field-work is perhaps by its nature more suited to investigations in microeconomics, being essentially an exploration that takes place at the plant or firm level. This has been the focus of this paper. Wider implications can often be drawn from this microeconomic work, as in Blinder's (1991) study, whose importance is really for macroeconomics.

The scope of this paper has been broad, yet its purpose is simple: too illuminate the common ground that Coase, as a field-worker has had with the Greats of economics in the eighteenth, nineteenth, twentieth and twenty first centuries. The domain of this 
paper is best described by a kind of Venn diagram, starting with all economics, in which there is a large proper sub-set of microeconomics (the primary intellectual playground of Smith, Marshall, Coase and Ostrom), and within which there is a further proper subset of managerial and decision economics (to which, in generous part, Smith, Marshall, Coase and Ostrom contributed). But the implications that this kind of work may have, as expounded by Coase and others, can extend much beyond this disciplinary base.

\section{Acknowledgments}

The author is grateful to the Editor of this special issue, Professor Lowell Jacobsen, for his detailed comments on previous draft and well-judged steering to further literature, and to an anonymous referee for thorough and searching criticism, which ultimately led to a much improved manuscript. The author remains responsible for any remaining errors of omission or commission.

\section{References}

Arena R, Quere M (eds). 2003. The Economics of Alfred Marshall: Revisiting Marshall's Legacy, Palgrave Macmillan: London.

Becattini G. 2011. From the Wanderjahre to the revival of Marshall's industrial economics. In Marshall, Marshallians and Industrial Economics, Raffaelli T, Nishizawa T, Cook S (eds). Routledge: Oxford; 1-9.

Becker GS. 1976. The Economic Approach to Human Behavior, University of Chicago Press: Chicago.

Benham A, Benham L. 2001. The Costs of Exchange. Ronald Coase Institute Working Paper Series, Number 1, July.

Blinder AS. 1991. Why are prices sticky? Preliminary results from an interview study. American Economic Review 81 (2): 89-96.

Brown G. 2010. Beyond the Crash: overcoming the first crisis of globalization, Simon and Schuster: London.

Buchanan J. 1968. The Demand and Supply of Public Goods, Rand McNally: Chicago.

Carroll, L. (aka Charles Lutwidge Dodgson).1865. Alice's Adventures in Wonderland, Macmillan: London. 
Coase RH. 1937. The nature of the firm. Economica 4(16): 386-405.

Coase RH. 1960. The problem of social cost. Journal of Law and Economics 3: 1-44.

Coase RH. 1972. Industrial organization: a proposal for research. In Fuchs VR (ed). 1972. Economic Research: Retrospect and Prospect Vol 3: Policy Issues and Research Opportunities in Industrial Organization, NBER: New York; 59-73.

Coase RH. 1978. Economics and contiguous disciplines. Journal of Legal Studies 7: 201-11.

Coase RH. 1988. The nature of the firm: origin, meaning, influence. Journal of Law Economics and Organization 4: 3-47.

Coase RH. 1991. The institutional structure of production.

http://www.nobelprize.org/nobel_prizes/economic-sciences/laureates/1991/coaselecture.html [accessed 19 October 2014]

Coase RH. 1992. The institutional structure of production, American Economic Review 82(4): 713-719.

Coase RH. 1994. Arnold Plant. In Essays on Economics and Economists, University of Chicago Press: Chicago; 176-84.

Coase RH. 2000. The acquisition of Fisher Body by General Motors. Journal of Law and Economics 48: 15-31.

Coase RH. 2006. The conduct of economics: the example of Fisher Body and General Motors. Journal of Economics \& Management Strategy 15(2): 255-278.

Coase RH, Wang N. 2011. The industrial structure of production: a research agenda for innovation in an entrepreneurial economy. Entrepreneurship Research Journal 1(2): 2157-5665.

Commons JR. 1931. Institutional economics. American Economic Review 21: 648-657.

Cook SJ. 2009. The Intellectual Foundations of Alfred Marshall's Economics Science: A Rounded Globe of Knowledge, Cambridge University Press: Cambridge, UK.

Cooter, R .1988. The Coase theorem. In The New Palgrave: a Dictionary of Economics,Eatwell J, Milgate M, Newman P (eds). Stockton Press; New York, NY; (1) 457-60.

Dorfman R, Samuelson PA, Solow RM. 1958. Linear Programming and Economic Analysis, McGraw-Hill: New York. 
Dow SC, Earl PE (eds). 1999. Contingency, Complexity and the Theory of the Firm: essays in honour of Brian J. Loasby, Edward Elgar: Cheltenham, UK.

Economist, The. 2012. Elinor Ostrom, defender of the commons, died on June 12th, aged 78. http://www.economist.com/node/21557717 [accessed 24 February 2014]

Eisenhardt K.1989. Building theories from case study research. Academy of Management Review 14(4): 532-550.

Ellickson, RC. 1991. The case for Coase and against Coaseanism. Yale Law Journal 99: 611-33.

Fay, CR. 1956. Adam Smith: and the Scotland of his day, Cambridge University Press: Cambridge, UK.

Fellner W. 1960. Competition among the Few: oligopoly and similar market structures. Knopf: New York, NY.

Feldstein M. 2000. The NBER-Sloan project on productivity change, American Economic Association Annual Meeting 2000. http://www.nber.org/sloan/AEAintro.html [accessed 19 October 2014]

Fennel LA. 2011. Ostrom's Law: property rights in the commons. International Journal of the Commons 5(1): 9-27.

Freeman R, Kleiner M. 1998. The last American shoe manufacturers. NBER Working Paper 6750.

Goldin C, Katz L. 1996. Technology, skill, and the wage structure. American Economic Review 96(2), 252-257.

Goldin C, Katz L. 1998. The origins of technology-skill complementarity. Quarterly Journal of Economics 113, 693-732.

Groenewegen P. 1995. A Soaring Eagle: Alfred Marshall, 1842-1924, Edward Elgar: Cheltenham, UK.

Hart N. 2012). Equilibrium and Evolution: Alfred Marshall and Marshallians, Palgrave Macmillan: London.

Hardin G. 1968. The tragedy of the commons. Science 162 (3859): 1243-1248.

Harrod R. 1951. The Life of John Maynard Keynes, Macmillan: London.

Hayek F von. 1944. The Road to Serfdom, Routledge: London. 
Helper S. 1991. Strategy and irreversibility in supplier relations. Business History Review 65(4), 781-824.

Helper S. 2000. You can observe a lot just by watching. American Economic Review 90 (2), 228.

Hicks J. 1939. Value and Capital: An Inquiry into Some Fundamental Principles of Economic Theory. Oxford: Clarendon Press.

Ichniowski C, Prennushi G, Shaw K. 1997. The effects of human resource management practices on productivity. American Economic Review 87(3): 291-313.

Janssen MA, Holahan R, Lee A, Ostrom E. 2010. Lab experiment for the study of social-ecological systems. Science 328(5978): 613-617.

Keynes JM. 1924. Alfred Marshall, 1842-1924. Economic Journal 34 (135): 311-372.

Klaes M. 2000. The history of the concept of transaction costs: neglected aspects.

Journal of the History of Economics Thought 22 (2): 191-216.

Klein B. 2007. The economic lessons of Fisher Body-General Motors. International Journal of the Economics of Business 14(1): 1-36.

Lazear E P. 2000. Performance pay and productivity. American Economic Review 90: $1346-1361$.

Loasby BJ. 1978. Whatever happened to Marshall's theory of value? Scottish Journal of Political Economy 25 (1): 1-12.

Lyons PJ. 2013. Ronald Coase, a law professor and leading economist, dies at 102, The New York Times, September 4, A20.

http://www.nytimes.com/2013/09/04/business/economy/ronald-h-coase-nobel-winningeconomist-dies-at-102.html? r=0 [Accessed 16 February 2014]

Marchionatti R. 2003. Dealing with complexity: Marshall and Keynes on the nature of economic thinking. In Arena R, Quere M (eds)The Economics of Alfred Marshall:

Revisiting Marshall's Legacy, Palgrave Macmillan; London: 32-52.

Marshall A. 1890. Principles of Economics, Macmillan: London.

Marshall A. 1897. The old generation of economists and the new. Quarterly Journal of Economics 11(2): 115-135.

Marshall A. 1919. Industry and Trade, Macmillan: London.

Marshall A, Marshall MP. 1879. The Economics of Industry, Macmillan: London.

Marshall MP. 1947. What I Remember, Cambridge University Press: Cambridge, UK. 
McCloskey DN. 1985. The Rhetoric of Economics, University of Wisconsin Press: Madison, WI.

Nell EJ, Errovaki K. 2013. Rational Econometric Man: transforming structural econometrics, Edward Elgar: Cheltenham, UK.

Ostrom E. 1986. An agenda for the study of institutions. Public Choice 48: 3-25.

Ostrom E. 1990. Governing the Commons: the evolution of institutions for collective action, CUP: Cambridge.

Ostrom E. 1992. Property rights regimes and natural resources: a conceptual analysis. Land Economics 68: 249-262.

Ostrom E. 2000. Collective action and the evolution of social norms. Journal of Economic Perspectives 14, 137-158.

Ostrom E. 2010. Beyond markets and states: polycentric governances and complex economic systems. American Economic Review 100: 641-672.

Posner R. 1993. Nobel Laureate Ronald Coase and methodology. The Journal of Economic Perspectives 7(4): 195-210.

Piore M. 1979. Qualitative research techniques in economics. Administrative Science Quarterly 24: 560-569.

Raffaelli T, Nishizawa T, Cook S (eds). 2011. Marshall, Marshallians and Industrial Economics, Routledge: Oxford.

Reid GC. 1987. Applying field research techniques to the business enterprise. International Journal of Social Economics 14: 3-25.

Reid GC. 1992. A note on the design and structure of a small firms' relational database. Small Business Economics 4, 9 -14.

Reid GC. 1993. Small Business Enterprise: an economic analysis, Routledge: London.

Reid GC, Jacobsen LR, Anderson ME. 1993. Profiles in Small Business: a competitive strategy approach, Routledge: London.

Reid GC. 2007. The Foundations of Small Business Enterprise: an entrepreneurial analysis of small firm inception and growth, Routledge: London.

Reid GC, Smith JA. 2008. Risk Appraisal and Venture Capital in High Technology New Ventures, Routledge: London.

Robbins L. 1932. An Essay on the Nature and Significance of Economic Science, Macmillan: London.

Rubin E, Hooker JJ. 1965. The statistical milieu of Adam Smith: II. The American Statistician 19 (2): 49-51. 
Smith A. 1762. Lectures on Jurisprudence, Meek RL, Raphael DD, Stein PG (eds). Volume V of the Glasgow Edition of The Works and Correspondence of Adam Smith, Oxford University Press: Oxford.

Smith A. 1776. An Inquiry into the Nature and Causes of the Wealth of Nations, Edited Skinner A, Wilson T (eds). Glasgow Edition, Oxford University Press: Oxford.

Swann PGM. 2008. Putting Econometrics in its Place, Edward Elgar: Cheltenham.

Tashakkori A, Teddlie C. 1998. Mixed Methodology: Combining Qualitative and Quantitative Approaches, Sage: Thousand Oaks, CA.

Tashakkori A, Teddlie C (eds). 2003. Handbook of Mixed Methods in Social and Behavioral Research, Sage: Thousand Oaks, CA.

Teddlie C, Tashakkori A. 2009. Foundations of Mixed Methods Research: Integrating Quantitative and Qualitative Approaches in the Social and Behavioral Sciences, Sage: Thousand Oaks, CA.

Terjesen S, Wang N. 2013. Coase on entrepreneurship. Small Business Economics 40: 173-184.

Usher D. 1998. The Coase theorem is tautological, incoherent or wrong. Economic Letters 61: 3-11.

Vitalari N, Shaugnessy H. 2012. The Elastic Enterprise: the new manifesto for business revolution, Telemachus Press: Sarasota, FL.

Walker JA, Gardner R, Ostrom E. 1990. Rent dissipation in a limited-access common pool resource: experimental evidence. Journal of Environmental Economics and Management 19: 203-211.

Walras L. 1874. Éléments d'économie politique pure, ou théorie de la richesse sociale, (Elements of Pure Economics, or the theory of social wealth) Jaffé W (transl). 1954, George Allen and Unwin: London.

Whitaker JK. 1996. The Correspondence of Alfred Marshall, Economist, Cambridge University Press: Cambridge UK.

Wright, J. 2007. Klein v. Coase III: Fisher Body-General Motors again (and again) - 14 March 2007 http://truthonthemarket.com/2007/03/14/klein-v-coase-iii-fisher-bodygeneral-motors-again-and-again/ [Accessed 31January 2014]. 